\title{
HOW AND WHEN IS SELF-EFFICACY RELATED TO ENTREPRENEURIAL INTENTIONS: EXPLORING THE ROLE OF ENTREPRENEURIAL OUTCOME EXPECTATIONS AND SUBJECTIVE NORMS
}

CÓMO Y CUÁNDO SE RELACIONA LA AUTOEFICACIA CON LAS INTENCIONES EMPRENDEDORAS: EL PAPEL DE LAS EXPECTATIVAS DE RESULTADOS Y LAS NORMAS SUBJETIVAS

Susana C. Santos (Rowan University, Estados Unidos) *

Eric W. Liguori (Rowan University, Estados Unidos) ${ }^{* *}$

\begin{abstract}
This study investigates how and when general self-efficacy is related to entrepreneurial intentions. We propose that entrepreneurial outcome expectations function as a mediator in this relationship, while subjective norms act as a moderator. Using a sample of 1052 students from U.S. Public Universities, we tested a moderated mediation model. Results showed that general self-efficacy is positively related to entrepreneurial intentions through the mediating effect of entrepreneurial outcome expectations, and that this relationship is significantly positive for individuals with favourable subjective norms towards entrepreneurship, while significantly negative for individuals with less favourable subjective norms. These findings both contribute to literature on entrepreneurial intentions and reinforces the need for educators and policy makers to ensure programs manage outcome expectations and recognize the value of peer, parent, and mentor role models.
\end{abstract}

Keywords: entrepreneurial intentions, self-efficacy, entrepreneurial outcome expectations, subjective norms.

JEL code: L26.

\section{Resumen}

Este estudio investiga cómo y cuándo la autoeficacia general está relacionada con las intenciones emprendedoras. Proponemos que las expectativas de resultados emprendedores funcionan como mediador en esta relación, mientras que las normas subjetivas actúan como moderador. Usando una muestra de 1052 estudiantes de universidades públicas de Estados Unidos, probamos un modelo de mediación moderada. Los resultados mostraron que la autoeficacia general se relaciona positivamente con las intenciones emprendedoras a través del efecto mediador de las expectativas de resultados emprendedores, y que esta relación es significativamente positiva para individuos con normas subjetivas favorables hacia el emprendimiento, mientras que es significativamente

\footnotetext{
* Rowan University, New Jersey, EEUU, santossc@rowan.edu.

** Rowan University, New Jersey, EEUU, liguori@rowan.edu.

Recibido: 16 de enero de 2019. Aceptado: 13 de mayo de 2019.
} 
Santos, S.

How and when is self-efficacy related to entrepreneurial intentions: Exploring the role of entrepreneurial outcome expectations and subjective norms

negativa para individuos con normas subjetivas menos favorables. Estos hallazgos contribuyen a la literatura sobre emprendimiento. Además, también refuerzan la necesidad de que los educadores y los encargados de formular políticas se aseguren de que los programas tienen en cuenta las expectativas de resultados y reconocen el valor de los compañeros, padres y mentores como modelos de conducta

\section{INTRODUCTION}

Entrepreneurial intentions refer to the will and wish of considering the creation of a new venture (e.g., Bird, 1992; Bird \& Schjoedt, 2009). Intentions are a necessary precursor of entrepreneurial behaviors (Fayolle et al., 2006) and new venture creation (Lee \& Wong, 2004). Based on a multitude of perceptions, individuals form their positive or negative entrepreneurial intentions (e.g., Liñán \& Chen, 2009). Prior research has systematically shown the intentions of carrying out entrepreneurial behaviors is affected by several factors, such as one's needs, values, wants, habits, and beliefs (Bird, 1988; Lee \&Wong, 2004; Liñán \& Fayolle, 2015).

Recently, social cognitive career theory was presented as a robust theoretical framework to study individual entrepreneurial activity (Liguori et al., 2018). This framework constitutes an alternative to the classic intention based-models (i.e., Theory of Planned Behavior (Ajzen, 1991; 2012; Krueger, 1993) which have been criticized for considering entrepreneurship as a linear process and undermining the uncertainty and non-linearity of the entrepreneurial journey (cf., Neck \& Greene, 2011; Neck \& Corbett, 2018; Brännback et al., 2007). As such, the unidirectional and linear nature of the classic intentions-based models (Ajzen, 1991; 2012; Krueger, 1993) "make it difficult for them to account for reciprocal, exponential, and/or moderating relationships" (Liguori et al., 2018, p. 68).

The conceptual framework on the social cognitive career approach to entrepreneurial intentions presents a set of propositions explaining the relationship between person-level inputs (e.g., general self-efficacy, gender) and environmental and background inputs (e.g., prior work experience, family business exposure) on entrepreneurial self-efficacy and entrepreneurial outcome expectations, which in turn affect entrepreneurial intentions (Liguori, Bendickson \& McDowell, 2018). While this theory has been explored in the context of entrepreneurial intentions, empirical tests to this model are still scarce. In this study we address this gap by empirically testing a part of this conceptual model, specifically testing if entrepreneurial outcome expectations act as a mediator mechanism in the relationship between general self-efficacy and entrepreneurial intentions. This responds to the how question: How is self-efficacy related to entrepreneurial intentions. Moreover, we extend Liguori, Bendickson and McDowell (2018) model by theorizing and testing subjective norms as a boundary condition in this relationship, meaning that subjective norms are a relevant moderator variable. Here we respond to the when question: When is selfefficacy related to entrepreneurial intentions. It is important to clarify that when refers to conditional effects and not to time related effects.

Self-efficacy refers to the individual's belief on his / her ability to successfully perform the behaviour (Bandura, 1982; 1997). Self-efficacy has been identified as a key antecedent of entrepreneurial intentions (e.g. Boyd \& Vozikis 1994; Carr \& Sequeira, 2007; Mauer et al., 2013; Zhao et al., 2005; Spagnoli et al., 2016), business venture launch and success (Chen et al., 1998), and business performance (Forbes, 2005; Hmieleski \& Baron, 2008; Hmieleski \& Corbett, 2008). 
Self-efficacy is important for entrepreneurs because they must be confident in their abilities to perform different and often unanticipated tasks in uncertain situations (Baum \& Locke, 2004).

Entrepreneurial outcome expectations refer to the expected consequence of performing the targeted behavior (Lent \& Brown, 2008). It is defined as the expected result or outcome of intentional actions in which the individual decides to engage (Bandura, 2001; Vanevenhoven \& Liguori, 2013). In the context of entrepreneurship, these outcome expectations are specifically related to entrepreneurial behaviors, of which entrepreneurial intentions are a precursor (Krueger et al., 2000).

Perceived social norms refer to the individual's assessment on the social pressure imposed by reference people (i.e., family, friends, mentors or significant others) to carry out - or not to carry out - a specific behavior (Ajzen, 2002). Particularly relevant for entrepreneurial intentions are the opinions of the others on the decision to pursue entrepreneurial activities (Carr \& Sequeira, 2007). These pressures have a strong or weak role in creation of intention depending on background of the individual (Fayolle et al., 2006). Prior research showed that this type of norms tends to contribute weakly to intention (Armitage \& Conner, 2001) for individuals with strong internal locus of control (Ajzen, 2002) than for those with a strong action orientation (Bagozzi, 1992). Yet, others found support for a significant direct and indirect effect of prior family business exposure on entrepreneurial intent, with subjective norms mediating the relationship (Carr \& Sequeira, 2007).

Overall, individuals decide to pursuit entrepreneurial activities based on their personal preference or attraction towards entrepreneurship, their perceived behavioral control, and their perceived subjective norms (Liñán, 2004). The literature on entrepreneurial intentions has shown a proliferation of scholarly work on self-efficacy (Boyd \& Vozikis 1994; Carr \& Sequeira, 2007; Mauer et al., 2013; Zhao et al., 2005), outcome expectations (Kassean et al., 2015) and subjective norms (Liñán, 2008) as antecedents of entrepreneurial intentions. However, there is still “a considerable need to provide some ordering and systematization in this research to contribute towards further advancement in the field” (Liñán \& Fayolle, 2015, p. 908). In this study we take this call, focusing on how (under which mechanism) and when (under which conditions) selfefficacy is related to entrepreneurial intentions. Grounded in social cognitive career theory (Lent et al., 2002) and building on the entrepreneurial intention literature (cf., Liñán, 2008, Liñán \& Fayolle, 2015), this study explores outcome expectations as a mechanism (how), and subjective norms as a condition (when) that matter in the effect of self-efficacy on entrepreneurial intentions.

\section{THEORETICAL BACKGROUND}

\subsection{Entrepreneurial Outcome Expectations as a Mechanism}

Self-efficacy is important for entrepreneurs because they must be confident in their abilities to perform different and often unanticipated tasks in uncertain situations (Baum \& Locke, 2004). Individuals with high self-efficacy are likely to persist when problems arise, and actively seek out challenges and, by extension, challenging opportunities (Bandura, 1997). (Entrepreneurial) Selfefficacy is positively related to entrepreneurial intentions, meaning that individuals with high beliefs on their own skills, are more likely to report the willingness to engage in entrepreneurial activities (Boyd \& Vozikis, 1994; Wilson et al., 2007). 
In addition, self-efficacy is also likely to be related to the valence of the entrepreneurial outcome expectations that one builds for a behavior. Individuals with higher levels of self-efficacy might develop a more positive expectation on the outcome of their actions, as they are confident on their own ability to successfully accomplish the task (Lent \& Brown, 2008). On its turn, individuals with lower levels of self-efficacy are more likely to develop not such a positive outcome expectation. As such, and in line with prior research (Vanevenhoven \& Liguori, 2013) and social cognitive career theory (Lent \& Brown, 2008), self-efficacy is positively related to outcome expectations.

Outcome expectations, in their turn, are also related to entrepreneurial intentions (Liguori et al., 2018). In conditions of positive entrepreneurial outcome expectations (e.g., creating successful products / services; becoming wealthier; being his/her own boss), individuals are more likely to develop intentions for starting up a new venture. On the other side, when outcome expectations are mostly adverse (e.g., low financial rewards; increase personal debt; no independence and autonomy) intentions to engage in entrepreneurial activities are likely not as high.

Therefore, and in line with social cognitive career theory (Lent et al., 2002), we argue that an important mechanism that underlies the relationship between self-efficacy and entrepreneurial intentions is the positive outcome expectations individuals have about their start-up activities. Entrepreneurial outcome expectations may create additional resources to fuel the willingness to pursuit entrepreneurial activities. Consequently, we hypothesize the following:

Hypothesis 1: Entrepreneurial outcomes expectations mediate the relationship between general self-efficacy and entrepreneurial intentions.

\subsection{Subjective Norms as a Condition}

Subjective norms, as social pressures towards carrying out - or not carrying out - actions, have been considered to highly shape how individuals behave. Particularly important are the perceptions on the opinion of "reference people" (i.e., family, close friends, mentors, entrepreneurship faculty) on the decision to pursue the behaviour (Ajzen, 2002), here, entrepreneurial behaviour. As perceived age norms were found to have a positive influence on entrepreneurial intentions (Kautonen et al., 2011), variations in others' opinion towards entrepreneurial activities explain, at least to some extent, the disparities in the level of entrepreneurial intentions (Kautonen et al., 2015).

We expect that the subjective norms regarding entrepreneurship would determine the portfolio of possible alternative courses and desirable options for individuals intending to start their own venture. Subjective norms show the strongest effect on entrepreneurial intentions (Kautonen et al., 2015). When subjective norms are favourable to having one's own business, and as such the individual perceives positive attitudes from relevant others towards engagement in entrepreneurship, it is expected that the relationship between self-efficacy and entrepreneurial intentions is positive and more salient. On the other hand, when relevant social groups (such as family, friends and mentors) yield not favourable opinions towards entrepreneurship (e.g., considering the willingness to start a business as risky, not viable and not feasible), it is expected that the relationship between self-efficacy and entrepreneurial intentions is negative.

As a result of the above mentioned, we anticipate that subjective norms may interact with self-efficacy in the prediction of entrepreneurial intentions (see Figure 1). Hence, incorporating the role of subjective norms in the social cognitive career framework in entrepreneurial intentions 
(Liguori et al., 2018), we hypothesize that when subjective norms towards entrepreneurship are more favourable, the mediated positive effect of self-efficacy on entrepreneurial intentions through outcome expectations will be more salient.

Hypothesis 2a: Subjective norms moderate the indirect positive effect of general self-efficacy on individual's entrepreneurial intentions via entrepreneurial outcomes expectations, such that this effect is stronger for individuals with a favorable subjective norm.

Hypothesis 2b: Subjective norms moderate the indirect positive effect of general self-efficacy on individual's entrepreneurial intentions via entrepreneurial outcomes expectations, such that this effect is weaker for individuals with a non favorable subjective norm.

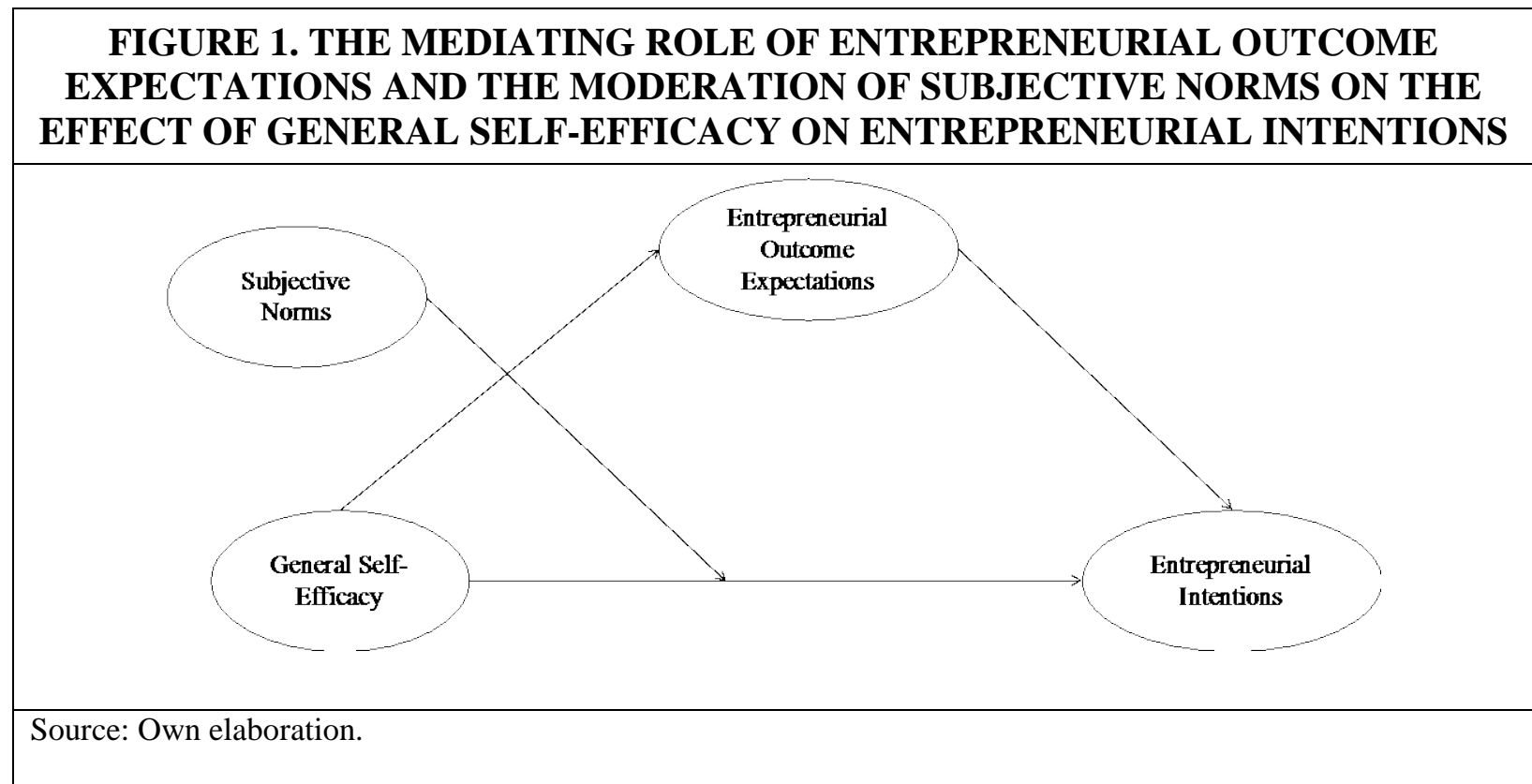

\section{METHOD}

\subsection{Data Collection and Sample}

Data used in this study is part of the Entrepreneurship Education Project, a global research initiative launched in 2010 focusing on "the phenomena of transformation from student to entrepreneur” (Vanevenhoven \& Liguori, 2013, p. 318). About the data collection procedure, surveys were distributed to professors teaching entrepreneurship around the world who, in turn, collected data from their students.

In the present study, we used a subset of the complete phase 2 dataset collected in 2011 (Vanevenhoven \& Liguori, 2013). Specifically, this study comprises a total of 1052 students from U.S. Public universities, that have not started a business (i.e., answered "No" to the question "Have you started a business that is currently operating?”) and are not considering starting a venture (i.e., answered "No" to the question "Are you considering starting a venture?”). The sample is mostly 
Santos, S.

How and when is self-efficacy related to entrepreneurial intentions: Exploring the role of entrepreneurial outcome expectations and subjective norms

comprised by female students (56.8 per cent), originally from the United States (93.3 per cent), being full-time students (85.2 per cent) and part-time employees for one year (80.2 per cent).

\subsection{Measures}

Entrepreneurial intention was measured with six items adapted from Thompson (2009). All the sentences were preceded by the following instruction: "Thinking of yourself, how true is it that you...". Sample items are "Are saving money to start a new venture"; "Spend time learning about starting a new venture" and "Intend to set up a new venture in the future". The items were answered on a seven point scale ranging from 1 "very untrue" to 7 "very true" $(\alpha=0.73)$.

General self-efficacy was measured with ten items adapted from Schwarzer, and Jerusalem (1995). Items were preceded by the instruction "Please indicate your agreement with each of the following statements" and answered in a five-point scale ranging from 1 "strongly disagree" to 5 "strongly agree". Sample items include "I can always manage to solve difficult problems if I try hard enough", "I am confident that I could deal efficiently with unexpected events", and "When I am confronted with a problem, I can usually find several solutions”. Exploratory factor analysis showed a single factor, with 50.62 per cent of variance explained, and all eigenvalue loadings above 0.56. $(\alpha=0.88)$.

Entrepreneurial outcome expectation was measured with four items inspired by Krueger (2000). All the sentences were preceded by the following instruction "To what extent do you expect to achieve the following outcomes by starting your own venture?". Items are "Financial rewards (personal wealth, increase personal income, etc.)”, "Independence/Autonomy (personal freedom, be your own boss, etc.)", "Personal rewards (public recognition, personal growth, to prove I can do it, etc.)" and "Family security (to secure future for family members, to build a business to pass on, etc.)". The items were answered on a seven point scale ranging from 1 "not at all” to 7 "very much" $(\alpha=0.89)$.

Subjective norms towards entrepreneurship was measured using six items adapted from Kolvereid and Isaksen (2006). Participants were asked to indicate the opinions of a set of people (parent(s), spouse/significant other, sibling(s), relatives, close friends and acquaintances) regarding their hypothetical choice to start a new venture $(\alpha=0.88)$.

Control variables. We controlled for gender (coded as a dummy variable; $0=$ female; $1=$ =male) and prior business exposure by parents/guardians (coded as a dummy variable; $0=$ No; $1=$ yes).

\section{RESULTS}

Table 1 reports the means, standard deviations, and correlations for all variables. Multiple analyses were conducted to investigate the threat of multicollinearity and common method variance in our data. Concerning the threat of multicollinearity, the highest correlation between any pair of independent variables was 0.23 (see Table 1). No variance inflation factor (VIF) scores were greater than 1.10, indicating that multicollinearity is not a concern, as each of these results falls within acceptable ranges (Fox, 1997; Neter et al., 1996; Tabachnick \& Fidell, 2001). In terms of common method variance threats, we followed the procedures described by Williams et al. (1989) and recommended by Podsakoff et al. (2012). We designed a model in which all the variables were loaded on one factor (common factor) to examine the fit of the confirmatory factor 
analysis model. The model fit for the single factor measure was poor $\left(\chi^{2}=763.086 ; \chi^{2} / d f=4.037\right.$; $p<0.001 ; C F I=0.478 ; R M S E A=0.124)$. These results rule out the possibility of common method variance and, consequently, it is unlikely to bias the results.

TABLE 1. MEANS, STANDARD-DEVIATIONS AND CORRELATIONS AMONG ALL VARIABLES

\begin{tabular}{lccccccc}
\hline & $M$. & $S . D$. & 1 & 2 & 3 & 4 & 5 \\
\cline { 2 - 8 } 1. Entrepreneurial intentions & 3.33 & 1.08 & & & & & \\
2. Gender & 0.43 & 0.50 & $0.11^{* * *}$ & & & & \\
3. Prior business exposure & 0.39 & 0.49 & $0.11^{* *}$ & -0.02 & & & \\
4. General self-efficacy & 3.92 & 0.50 & 0.06 & 0.01 & -0.04 & & \\
5. Entrepreneurial outcome expectations & 5.28 & 1.26 & $0.22^{* * *}$ & $-0.07^{*}$ & $0.12^{* * *}$ & $0.27^{* * *}$ & \\
6. Subjective norms & 5.29 & 0.87 & $0.21^{* * *}$ & -0.03 & $0.1^{* *}$ & 0.05 & $0.13^{* * *}$ \\
\hline
\end{tabular}

Notes: ${ }^{* * *}, p<0.001 ;{ }^{* *}, p<0.01 ;{ }^{*}, p<0.05$

Source: Own elaboration.

\subsection{The Mediation Role of Entrepreneurial Outcome Expectations}

To test the mediation of entrepreneurial outcome expectations in the relationship between general self-efficacy and entrepreneurial intentions (Hypothesis 1) we followed the recommendations on Aguinis and colleagues (2018) and used the bootstrapping method developed by Preacher et al., 2007. Accordingly, we used the PROCESS version 3 for SPSS (Hayes, 2017) with gender and prior business exposure as control variables, mediation model (Model 4), with 5000 bootstrapping samples to obtain 95 per cent bias-corrected confidence intervals (BCs CIs).

Results of the relevant regression analysis indicated that entrepreneurial outcome expectations did, in fact, fully mediate the influence of general self-efficacy on entrepreneurial intentions (Table 2). Results show that after accounting for gender and prior business exposure, general self-efficacy is positively related to outcome expectations $(B=0.66, p<0.001)$ and outcome expectations are positively associated with entrepreneurial intentions $(B=0.19, p<$ 0.001). With regard to the mediation effect (Hypothesis 1 ), the total effect of general self-efficacy on entrepreneurial intentions is non-significant $(B=0.11 ; p>0.05$; LLCI=-0.02; ULCI=0.24), but when general self-efficacy and outcome expectations are all included in the regression equation, the results support full mediation, as the indirect effect of general self-efficacy on entrepreneurial intentions through outcome expectations becomes significant (indirect effect $B=0.12$; LLCI=0.07; $\mathrm{ULCI}=0.17$ ). The fact that the bootstrap confidence interval is entirely above zero supports the conclusion that the indirect effect is positive (Hayes, 2017). These results support H1, according to which general self-efficacy is positively associated with entrepreneurial intentions through the experience of positive entrepreneurial outcome expectations. 
TABLE 2. RESULTS OF REGRESSION ANALYSIS TESTING THE MEDIATION MODEL

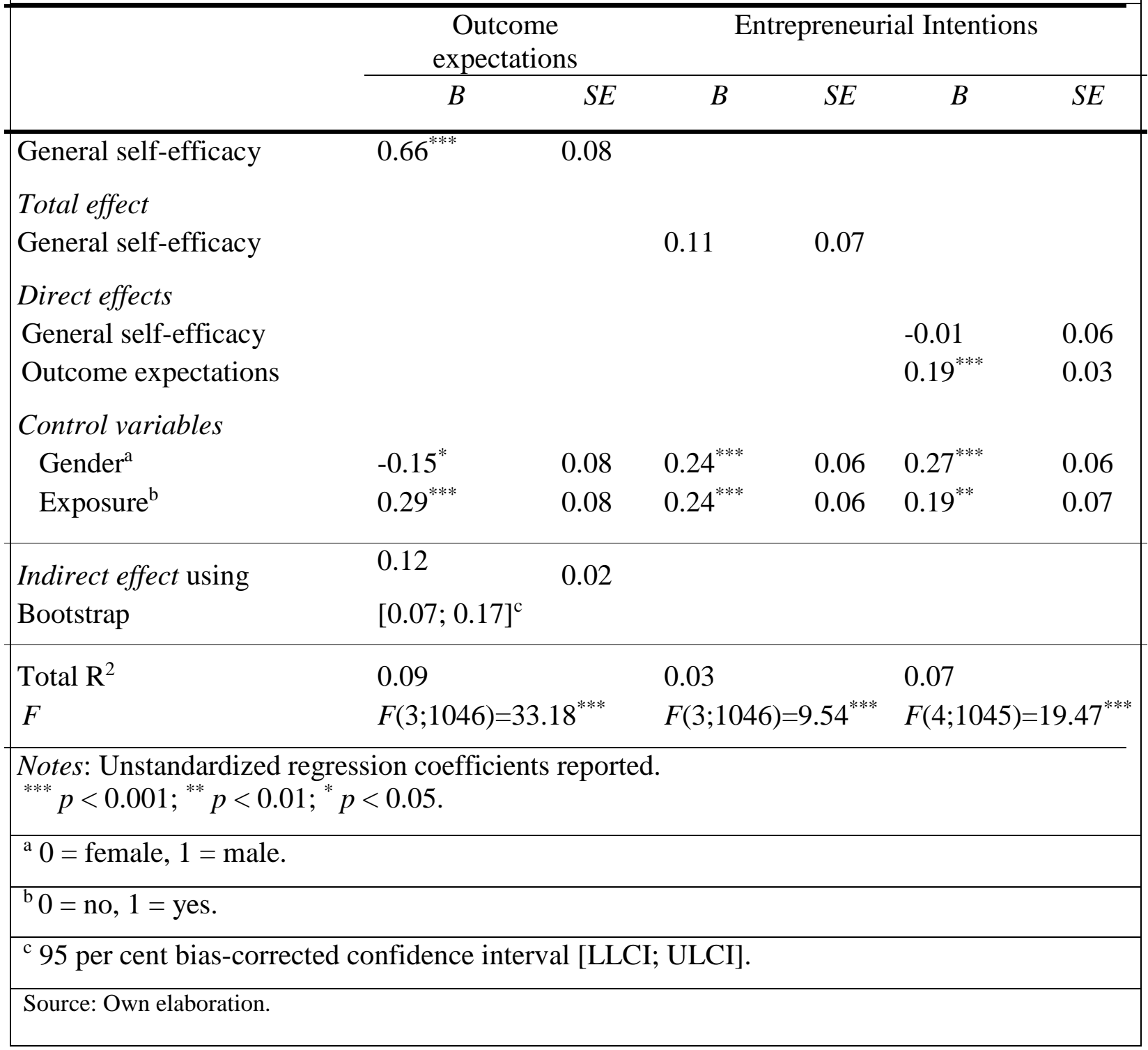

\subsection{The moderated mediation role of subjective norms}

To test the moderation role of subjective norms on the indirect positive effect of general selfefficacy on individual's entrepreneurial intentions via entrepreneurial outcomes expectations (Hypotheses 2a and 2b) we used Model 5 on the PROCESS macro version 3 for SPSS (Hayes, 2017) with gender and prior business exposure as control variables, with 5000 bootstrapping samples to obtain 95 per cent bias-corrected confidence intervals (BCs CIs). General self-efficacy and subjective norms were mean centred prior to the analysis. Table 3 presents the results of the moderated mediation and the conditional indirect effects. 
Results of this moderated mediation model revealed that, after controlling for gender and prior business exposure, the mediation effect of outcome expectations remains significant as general self-efficacy is positively related to outcome expectations $(B=0.66, p<0.001)$, outcome expectations are positively associated with entrepreneurial intentions $(B=0.17, p<0.001)$, and the indirect effect of general self-efficacy on entrepreneurial intentions through outcome expectations becomes significant (indirect effect $B=0.12$; LLCI=0.07; ULCI=0.17). In addition, and more important here, the interaction of general self-efficacy and subjective norms predicting entrepreneurial intentions was significant and positive $(B=0.22, p<0.001)$. The relationship between general self-efficacy and entrepreneurial intentions is negative and significant for individuals with less favourable subjective entrepreneurship norms (one standard deviation below the mean) $(B=-0.24 ; p<0.01)$, supporting Hypothesis $2 b$, and is positive and significant for individuals with more favourable subjective entrepreneurship norms (one standard deviation above the mean) ( $B=0.16 ; p \leq 0.05$ ), supporting Hypothesis 2a. For individuals with average subjective entrepreneurship norms (at the mean), the relationship between general self-efficacy and entrepreneurial intentions is not significant. 
Santos, S.

How and when is self-efficacy related to entrepreneurial intentions: Exploring the role of entrepreneurial outcome expectations and subjective norms

TABLE 3. RESULTS OF MODERATED MEDIATION REGRESSION ANALYSIS

\begin{tabular}{|c|c|c|c|c|c|c|}
\hline & \multicolumn{3}{|c|}{ Outcome expectations } & \multicolumn{3}{|c|}{ Entrepreneurial intentions } \\
\hline & $B$ & $S E$ & $95 \% C I$ & $B$ & $S E$ & $95 \% C I$ \\
\hline Constant & $5.24^{* * *}$ & 0.06 & $5.13 ; 5.35$ & $2.23^{* * *}$ & 0.15 & $1.94 ; 2.52$ \\
\hline \multicolumn{7}{|l|}{ Control variables } \\
\hline Gender & $-0.16^{*}$ & 0.08 & $-0.03 ;-0.01$ & $0.28^{* * *}$ & 0.06 & $0.16 ; 0.41$ \\
\hline Exposure & $0.29^{* * *}$ & 0.08 & $0.14 ; 0.44$ & $0.16^{* *}$ & 0.07 & $0.03 ; 0.29$ \\
\hline \multicolumn{7}{|l|}{ Main effects } \\
\hline General self-efficacy & $0.66^{* * *}$ & 0.08 & $0.51 ; 0.81$ & -0.01 & 0.07 & $-0.14 ; 0.12$ \\
\hline $\begin{array}{l}\text { Outcome } \\
\text { expectations }\end{array}$ & & & & $0.17^{* * *}$ & 0.03 & $0.12 ; 0.22$ \\
\hline Subjective norms & & & & $0.20^{* * *}$ & 0.04 & $0.12 ; 0.26$ \\
\hline \multicolumn{7}{|l|}{ Interaction } \\
\hline \multicolumn{7}{|l|}{ X Subjective norms } \\
\hline Total $\mathrm{R}^{2}$ & 0.09 & & & 0.11 & & \\
\hline$F$ & $F(3 ; 1046$ & $3.28^{* * *}$ & & $F(6 ; 1043$ & $1.31^{* * *}$ & \\
\hline
\end{tabular}

Conditional indirect

effect
Subjective norms
$-0.24^{* *}$
0.09
$-0.42 ;-0.05$

$1 S D$ below the

mean

Subjective norms

$\begin{array}{lll}-0.01 & 0.07 \quad-0.14,0.12\end{array}$

at the mean

Subjective norms

$0.16^{*}$

$0.09 \quad-0.01,0.32$

$1 S D$ above the

mean

Notes: All estimates for the moderated mediation model were also tested for significance using bias-corrected 95 per cent confidence intervals from 5000 bootstrap samples.

${ }^{* * *} p<0.001 ;{ }^{* *} p<0.01 ;{ }^{*} p \leq 0.05$.

Source: Own elaboration. 
To illustrate the interaction effect, we plotted the simple slopes for participants with less favourable subjective entrepreneurship norms (one standard deviation below the mean), participants with average subjective entrepreneurship norms (at the mean), and for participants with more favourable subjective entrepreneurship norms (one standard deviation above the mean). Figure 2 shows the moderating effect of the subjective norms on the relationship between general self-efficacy and entrepreneurial intentions.

\section{FIGURE 2. ENTREPRENEURIAL INTENTIONS AS A FUNCTION OF GENERAL} SELF-EFFICACY AND SUBJECTIVE NORMS

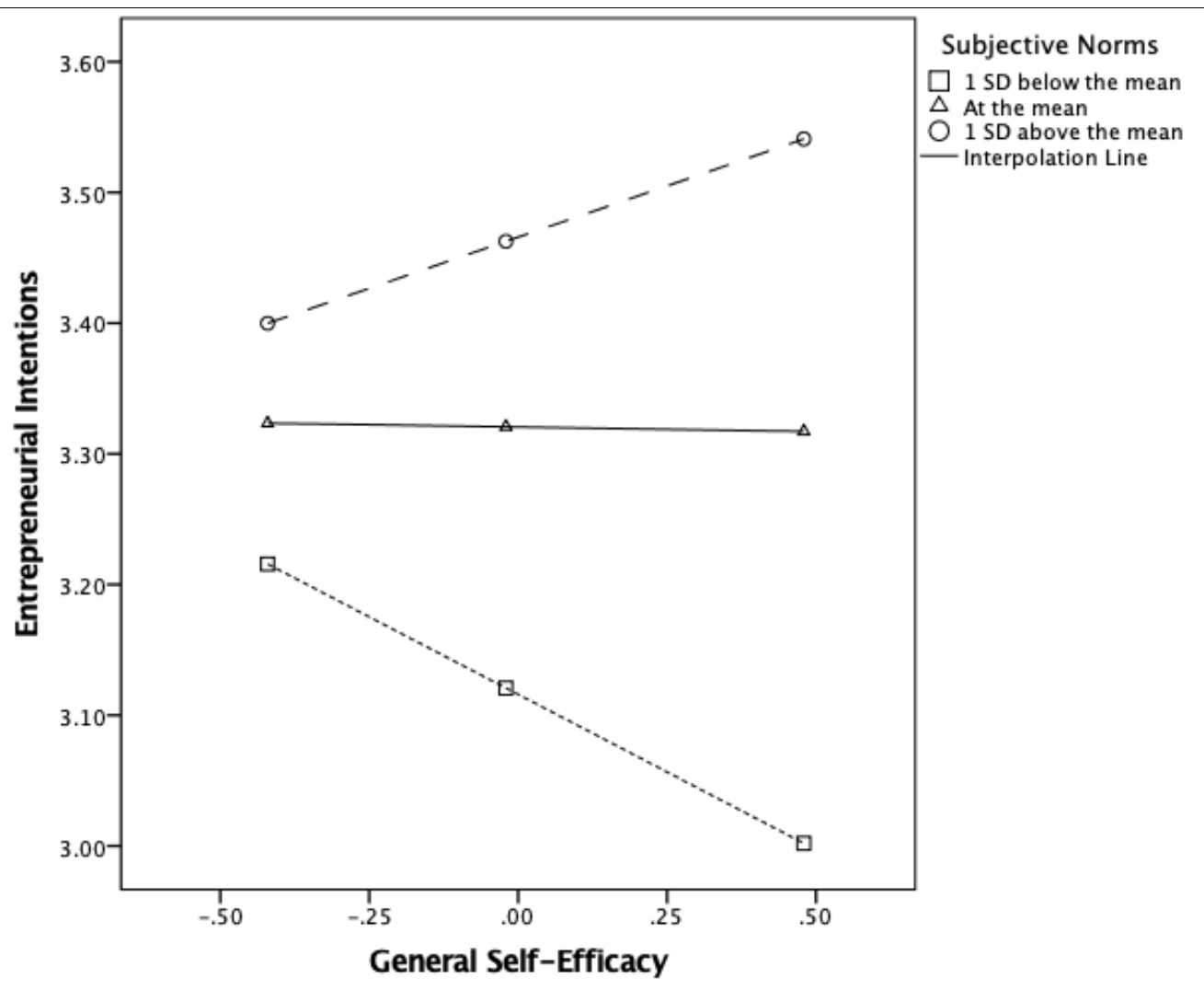

Source: Own elaboration.

\section{DISCUSSION}

The purpose of this study was to expand our knowledge and understanding on how and when general self-efficacy is related to entrepreneurial intentions. We tested part of the social cognitive career framework on entrepreneurial intentions and integrated the role of subjective norms. Specifically, we explore the mediating role of entrepreneurial outcome expectations and the moderating role of subjective norms on the relationship between general self-efficacy and entrepreneurial intentions. Using a sample of 1052 students from U.S. public universities, we found that entrepreneurial outcome expectations fully mediate the relationship between general 
Santos, S.

How and when is self-efficacy related to entrepreneurial intentions: Exploring the role of entrepreneurial outcome expectations and subjective norms

self-efficacy and entrepreneurial intentions, and that this effect is positive and significant for individuals with more favourable subjective norms and negative and significant for individuals with a less favourable subjective norms. These results support our hypotheses 1, 2a and 2b. Next, we discuss the theoretical and practical implications of these results.

\section{Theoretical and practical implications}

The literature on entrepreneurial intentions has rapidly grown, but there are still questions that need to be addressed (Liñán \& Fayolle, 2015). Specifically, the field is still scarce on testing models answering to the how and when questions regarding entrepreneurial intentions. Our study provides some initial contributions on this direction. We provide initial empirical support to Liguori et al. (2018) social cognitive career framework on entrepreneurial intentions and we propose that outcome expectations and subjective norms are not simply a predictor of entrepreneurial intentions, but they act respectively as a mechanism and boundary condition.

Our study also provides new insights on the role of entrepreneurial outcome expectations in entrepreneurial intentions. This variable is considerably underexplored in the entrepreneurial intention literature so far (Vanevenhoven \& Liguori, 2013) and here we uncover that it might have a very relevant role in the relationship between self-efficacy and entrepreneurial intentions. Lastly, we contributed to prior work on subjective norms and entrepreneurial intentions (e.g., Heuer \& Liñán, 2013; Maresch et al., 2016) clearly showing that others' opinions about entrepreneurship has a moderating role on the relationship between self-efficacy and entrepreneurial intentions. Specifically, when relevant others' opinions towards entrepreneurship is very favourable, the relationship between self-efficacy and entrepreneurial intentions is boosted; while when relevant others' opinions towards entrepreneurship is less favourable, the relationship between self-efficacy and entrepreneurial intentions is negative. By exploring the role of subjective norms, we build on the social cognitive career theory-informed model of entrepreneurial intentions.

\subsection{Limitations, Practical Contributions and Future Research}

The current study has some limitations that highlight promising research avenues. The first concern is our ability to make causal inferences due to the cross-sectional nature of the empirical design and the fact that all measures were self-reported and collected in the same moment of time. A longitudinal study design would be stronger in uncovering causalities and future research should benefit from this type of research design. Second, this study focused on entrepreneurial intentions and not on actual behavior. That noted, strong evidence supports a solid relationship between entrepreneurial intentions and actual entrepreneurial behavior, though additional longitudinal research is needed to explore a more fully specified model. Third, we based our analysis on data collected as part of the Entrepreneurship Education Project, which limits our measures to those that are available. Fortunately, this dataset was designed intentionally to capture a social cognitive career theory informed model, so this limitation was negligible. Other research avenues might want to explore team competencies (Santos et al., 2019) as antecedents of entrepreneurial intentions.

This study has relevant practical implications for entrepreneurship education. Managing entrepreneurial outcome expectations among students, such as creating awareness on the real consequences that might be expected from their startup activities, is important as it has a relevant role on entrepreneurial intentions, attitudes towards entrepreneurship (Spagnoli et al., 2017) and other cognitive processes (Santos et al., 2016). As such, educators should guide students through 
their entrepreneurial journey and provide guidance and clarification on outcome expectations, taking advantage of different learning contexts (e.g., Santos et al., 2018). In addition, entrepreneurship educators, decision and policy makers should also address the role of subjective norms, calling students attention for social pressures that family, friends and acquaintances instill on their intentions and future behavior. For decision and policy makers, our results also call for the need to spread the advantages of general self-efficacy and subjective norms as driver of entrepreneurial intentions. Particularly important, decision and policy makers may consider the relevance of integrating peers, family members and role models when they define/implement initiatives to enhance innovation/entrepreneurship, as the subjective norms perceived among these have an important role on entrepreneurial intentions. It is clear that by incorporating peers, family and other role models in university and local innovation/entrepreneurship activities, perceived subjective norms towards entrepreneurship are enhanced, and that positively impacts entrepreneurial intentions. Therefore, it is necessary to implement mechanisms and initiatives to integrate relevant others, beyond students, in innovation/entrepreneurship functions.

\section{REFERENCES}

Aguinis, H., Ramani, R. S., \& Alabduljader, N. (2018). What you see is what you get? Enhancing methodological transparency in management research. Academy of Management Annals, vol 12, $n^{\circ} 1$, pp. 83-110.

Ajzen, I. (1991). The theory of planned behavior. Organizational Behavior and Human Decision Processes, vol. 50, n ${ }^{\circ}$ 2, pp. 179-211.

Ajzen, I. (2002). Perceived behavioral control, self-efficacy, locus of control, and the theory of planned behavior. Journal of Applied Social Psychology, vol. 32, n 4, pp. 665-683.

Ajzen, I. (2012). The theory of planned behavior. In P. A. M. Van Lange, A. W. Kruglanski, \& E. T. Higgins (Eds.), The handbook of theories of social psychology, pp. 438-459. London: SAGE Publications.

Armitage, C. J., \& Conner, M. (2001). Efficacy of the theory of planned behaviour: A metaanalytic review. British Journal of Social Psychology, vol. 40, n 4, pp. 471-499.

Bagozzi, R. P. (1992). The self-regulation of attitudes, intentions, and behavior. Social Psychology Quarterly, vol. 55, n 2, pp. 178-204.

Bandura, A. (1982). Self-efficacy mechanism in human agency. The American Psychologist, vol. 37, $\mathrm{n}^{\circ} 2$, pp. 122-147.

Bandura, A. (1997). Self-efficacy: The exercise of control. New York: Freeman and Co.

Bandura, A. (2001). Social cognitive theory: An agentic perspective. Annual Review of Psychology, vol. 52, n ${ }^{\circ}$ 1, pp. 1-26.

Baum, J. R., \& Locke, E. A. (2004). The relationship of entrepreneurial traits, skills, and motivation to subsequent venture growth. Journal of Applied Psychology, vol. 89, nº 4, pp. 587-598.

Bird, B. J. (1988). Implementing entrepreneurial ideas: The case for intention. Academy of Management Review, vol. 13, $\mathrm{n}^{\circ}$ 3, pp. 442-453.

Bird, B. J. (1992). The operation of intentions in time: The emergence of the new venture. Entrepreneurship Theory and Practice, vol. 17, $\mathrm{n}^{0}$ 1, pp. 11-20.

Bird, B., \& Schjoedt, L. (2009). Entrepreneurial behavior: Its nature, scope, recent research, and agenda for future research. In A. Carsrud and M. Brännback (Eds.), Understanding the entrepreneurial mind: Opening the back box (pp. 327-358). Heidelberg: Springer. 
Boyd, N. G., \& Vozikis, G. S. (1994). The influence of self-efficacy on the development of entrepreneurial intentions and actions. Entrepreneurship Theory and Practice, vol. 18, $\mathrm{n}^{\mathrm{o}}$ 4, pp. 64-77.

Brännback, M., Carsrud, A. L., Kickul, J., \& Krueger, N. (2007). “watch out, Issac!!” - reconstructing entrepreneurial intentions. Regional Frontiers of Entrepreneurship Research, vol. 14, no 1, pp. 106-120.

Carr, J. C., \& Sequeira, J. M. (2007). Prior family business exposure as intergenerational influence and entrepreneurial intent: a theory and planned behavior approach. Journal of Business Research, vol. 60, $\mathrm{n}^{\mathrm{o}}$ 10, pp. 1090-1098.

Chen, C. C., Greene, P. G., \& Crick, A. (1998). Does self-efficacy distinguish entrepreneurs from managers? Journal of Business Venturing, vol. 13, nº 4, pp. 295-316.

Fayolle, A., Gailly, B., \& Lassas-Clerc, N. (2006). Assessing the impact of entrepreneurship education programmes: A new methodology. Journal of European Industrial Training, vol 30, no 9, pp. 701-720.

Forbes, D. (2005). The effects of strategic decision making on entrepreneurial self-efficacy. Entrepreneurship Theory and Practice, vol. 29, n 5, pp. 599-626.

Fox, J. (1997). Applied regression, linear models, and related methods. Sage, Thousand Oaks, CA. Hayes, A. F. (2017). Introduction to mediation, moderation, and conditional process analysis: A regression-based approach ( $2^{\text {nd }}$ Edition). New York, NY: The Guilford Press.

Heuer, A., \& Liñán, F. (2013). Testing alternative measures of subjective norms in entrepreneurial intention models. International Journal of Entrepreneurship and Small Business, vol. 19, $\mathrm{n}^{\mathrm{o}}$ 1, pp. 35-50.

Hmieleski, K. M., \& Baron, R. A. (2008). When does entrepreneurial self-efficacy enhance versus reduce firm performance? Strategic Entrepreneurship Journal, vol. 2, nº 1, pp. 57-72.

Hmieleski, K. M., \& Corbett, A. C. (2008). The contrasting interaction effects of improvisational behavior with entrepreneurial self-efficacy on new venture performance and entrepreneur work satisfaction. Journal of Business Venturing, vol. 23, nº 4, pp. 482-496.

Kassean, H., Vanevenhoven, J., Liguori, E., \& Winkel, D. E. (2015). Entrepreneurship education: a need for reflection, real-world experience and action. International Journal of Entrepreneurial Behavior \& Research, vol. 21, no 5, pp. 690-708.

Kautonen, T., Tornikoski, E. T., \& Kibler, E. (2011). Entrepreneurial intentions in the third age: the impact of perceived age norms. Small Business Economics, vol. 37, nº 2, pp. 219-234.

Kautonen, T., van Gelderen, M., \& Fink, M. (2015). Robustness of the theory of planned behavior in predicting entrepreneurial intentions and actions. Entrepreneurship Theory and Practice, vol. 39, $\mathrm{n}^{\mathrm{O}}$ 3, pp. 655-674.

Kolvereid, L. \& Isaksen, E. (2006). New business start-up and subsequent entry into selfemployment. Journal of Business Venturing, vol. 21, nº 6, pp. 866-885.

Krueger, N. F. (1993). The impact of prior entrepreneurial exposure on perceptions and new venture. Entrepreneurship Theory and Practice, vol. 18, n ${ }^{0} 1$, pp. 5-21.

Krueger, N. F. (2000). The cognitive infrastructure of opportunity emergence, Entrepreneurship Theory and Practice, vol. 24, n ${ }^{\circ}$ 3, pp. 5-23.

Krueger, N. F., Reilly, M. D., \& Carsrud, A. L. (2000). Competing models of entrepreneurial intentions. Journal of Business Venturing, vol. 15, n 5, pp. 411-432.

Lee, S. H., \& Wong, P. K. (2004). An exploratory study of technopreneurial intentions: A career anchor perspective. Journal of Business Venturing, vol. 19, $\mathrm{n}^{\circ}$ 1, pp. 7-28. 
Lent, R. W., \& Brown, S. D. (2008). Social cognitive career theory and subjective wellbeing in the context of work. Journal of Career Assessment, vol. 16, $\mathrm{n}^{0}$ 1, pp. 6-21.

Lent, R. W., Brown, S. D., \& Hackett, G. (2002). Social cognitive career theory. Career Choice and Development, $\mathrm{n}^{\circ} .4$, pp. 255-311.

Liguori, E. W., Bendickson, J. S., \& McDowell, W. C. (2018). Revisiting entrepreneurial intentions: a social cognitive career theory approach. International Entrepreneurship and Management Journal, vol. 14, $\mathrm{n}^{\mathrm{0}}$ 1, pp. 67-78.

Liñán, F. (2004). Intention-based models of entrepreneurship education. Piccolla Impresa/Small Business, vol. 3, $\mathrm{n}^{\circ}$ 1, pp. 11-35.

Liñán, F. (2008). Skill and value perceptions: how do they affect entrepreneurial intentions? International Entrepreneurship and Management Journal, vol. 4, nº 3, pp. 257-272.

Liñán, F., \& Chen, Y.-W. (2009). Development and cross-cultural application of a specific instrument to measure entrepreneurial intentions. Entrepreneurship Theory and Practice, vol. 33, n ${ }^{0}$ 3, pp. 593-617.

Liñán, F., \& Fayolle, A. (2015). A systematic literature review on entrepreneurial intentions: citation, thematic analyses, and research agenda. International Entrepreneurship and Management Journal, vol. 11, n 4, pp. 907-933.

Maresch, D., Harms, R., Kailer, N., \& Wimmer-Wurm, B. (2016). The impact of entrepreneurship education on the entrepreneurial intention of students in science and engineering versus business studies university programs. Technological Forecasting and Social Change, $\mathrm{n}^{\mathrm{o}}$ 104, pp. 172-179.

Mauer, R., Eckerle, P., \& Brettel, M. (2013). Adding missing parts to the intention puzzle in entrepreneurship education: entrepreneurial self-efficacy, its antecedents and their direct and mediated effect. In Smallbone, D., Leitão, J., Raposo, M., Welter, F. (Eds.). Frontiers in European Entrepreneurship Research, pp. 73-86. Cheltenham, UK: Edward Elgar.

Neck, H. M., \& Corbett, A. C. (2018). The scholarship of teaching and learning entrepreneurship. Entrepreneurship Education and Pedagogy, vol. 1, n 1, pp. 8-41.

Neck, H. M., \& Greene, P. G. (2011). Entrepreneurship education: known worlds and new frontiers. Journal of Small Business Management, vol. 49, $\mathrm{n}^{\circ}$ 1, pp. 55-70.

Neter, J., Kutner, M. H., Nachtsheim, C. J., \& Wasserman, W. (1996). Applied linear statistical models. Irwin, Chicago.

Podsakoff, P. M., MacKenzie, S. B., \& Podsakoff, N. P. (2012). Sources of method bias in social science research and recommendations on how to control It. Annual Review of Psychology, vol. 63, no 1, pp. 539-569.

Preacher, K. J., Rucker, D. D., \& Hayes, A. F. (2007). Addressing moderated mediation hypotheses: Theory, methods, and prescriptions. Multivariate Behavioral Research, vol. 42, no 1 , pp. 185-227.

Santos, S. C., Costa, S. F., Neumeyer, X. \& Caetano, A. (2016). Bridging entrepreneurial cognition research and entrepreneurship education: What and how. In Michael Morris \& Eric Liguori (Ed.) Annals of Entrepreneurship Education and Pedagogy - 2016, pp. 83-108. Edward Elgar Publishing.

Santos, S. C., Morris, M., Caetano, A., Costa, S. F. \& Neumeyer, X. (2019). Team entrepreneurial competence: Multilevel effects on individual cognitive strategies. International Journal of Entrepreneurial Behavior and Research, doi.org/10.1108/IJEBR-03-2018-0126 
Santos, S.

How and when is self-efficacy related to entrepreneurial intentions: Exploring the role of entrepreneurial outcome expectations and subjective norms

Santos, S. C., Neumeyer, X., \& Morris, M. H. (2018). Entrepreneurship education in a poverty context: An empowerment perspective. Journal of Small Business Management. doi.org/10.1111/jsbm.12485

Schwarzer, R., \& Jerusalem, M. (1995). Generalized self-efficacy scale. In J. Weinman, S. Wright, \& M. Johnston (Eds.) Measures in health psychology: A user's portfolio. Causal and control beliefs, pp. 35-37. Windsor, England: NFER-NELSON.

Spagnoli, P., Santos, S. C. \& Caetano, A. (2016). A contribution toward the adaptation and validation of the entrepreneurial self-efficacy scale in Italy and Portugal. Journal of Career Assessment, vol. 25, $\mathrm{n}^{\circ}$ 4, pp. 670-687.

Spagnoli, P., Santos, S. C., \& Caetano, A. (2017). Adaptation of the Attitude Toward Enterprise Test in the Italian high school and university contexts. Journal of Developmental Entrepreneurship, vol. 22, no 1, doi: http://dx.doi.org/10.1142/S1084946717500054

Tabachnick, B. G., \& Fidell, L. S. (2001). Using multivariate statistics. Allyn and Bacon, Boston.

Thompson, E.R. (2009). Individual entrepreneurial intent: Construct clarification and development of an internationally reliable metric. Entrepreneurship Theory and Practice, vol. 33, $\mathrm{n}^{\circ}$ 3, pp. 669-694.

Vanevenhoven, J., \& Liguori, E. (2013). The impact of entrepreneurship education: Introducing the Entrepreneurship Education Project. Journal of Small Business Management, vol. 51, $n^{\circ}$ 3, pp. 315-328.

Williams, L. J., Cote, J. A., \& Buckley, M. R. (1989). Lack of method variance in self-reported affect and perceptions at work: Reality or artifact? Journal of Applied Psychology, vol. 74, $\mathrm{n}^{\mathrm{o}}$ 3, pp. 462-468.

Wilson, F., Kickul, J., \& Marlino, D. (2007). Gender, entrepreneurial self-efficacy, and entrepreneurial career intentions: Implications for entrepreneurship education. Entrepreneurship Theory and Practice, vol. 31, n 3, pp. 387-406.

Zhao, H., Seibert, S., \& Hills, G. (2005). The mediating role of self-efficacy in the development of entrepreneurial intentions. Journal of Applied Psychology, vol. 90, n º, pp. 1265-1272. 